\title{
HOUSING PRICE DYNAMICS WITHIN \\ A METROPOLITAN AREA
}

Karl E. Case

Christopher J. Mayer

Working Paper No. 5182

\section{NATIONAL BUREAU OF ECONOMIC RESEARCH 1050 Massachusetts Avenue \\ Cambridge, MA 02138 \\ July 1995}

This paper was prepared for the 1994 NBER Conference on Housing and Public Policy. The authors wish to thank Katharine Bradbury, Sara Ellison, and seminar participants at Harvard University for helpful comments and Anna Godlewska, Bill Gouvea, Julie Hu, and especially Karen Therien for excellent research assistance. This paper was prepared as part of the NBER Study on Housing Dynamics and was presented at the NBER Study Conference. Any opinions expressed are those of the authors and not those of the National Bureau of Economic Research.

(c) 1995 by Karl E. Case and Christopher J. Mayer. All rights reserved. Short sections of text, not to exceed two paragraphs, may be quoted without explicit permission provided that full credit, including $\odot$ notice, is given to the source. 


\title{
HOUSING PRICE DYNAMICS WITHIN \\ A METROPOLITAN AREA
}

\begin{abstract}
This paper analyzes the pattern of cross-sectional house price appreciation in the Boston metropolitan area from 1982 to 1994 . The empirical results are consistent with many of the predictions of a standard urban model in which towns have a fixed set of locational attributes and amenities. In particular, the evidence suggests that house prices in towns with a large share of residents working in the manufacturing sector in 1980 grew less quickly in the ensuing years when aggregate manufacturing employment fell. As baby boomers moved into middle age, house values appreciated faster in towns with a larger initial percentage of middle-aged residents. Housing values rose more slowly in towns that allowed additional construction, and values rose faster in towns closer to Boston. Finally, as fewer families had children who attended public schools statewide, the price premium associated with housing in towns with good schools fell. All of these findings support the view that town amenities and public services are not easily replicated or quickly adaptable to shifts in demand, even within a metropolitan area.
\end{abstract}

Karl E. Case

Department of Economics

Wellesley College

Wellesley, MA 02181
Christopher J. Mayer

Federal Reserve Bank of Boston

PO Box 2076

Boston, MA 02106 


\section{Introduction}

Recent studies have shown interesting and provocative patterns of housing price appreciation and depreciation over the cycle in volatile markets. Smith and Tesarek (1991) present evidence that prices of "high quality" homes in the Houston area appreciated faster during the boom, fell further during the bust, and recovered more rapidly in the more recent expansion than did "low quality" homes. Mayer (1993) shows that a comparable pattern of increased volatility for high-priced homes existed in four cities during the 1970s and mid 1980s. Case and Shiller (1994) find similar results for Los Angeles but the opposite result for Boston, where lower-tier properties appreciated the most during the boom and their prices fell further during the bust. More recently, they find that in Boston, high-tier properties have regained much of the value lost during the bust, while lowertier properties continue near their cyclical lows. Poterba (1991) shows that high-priced properties appreciated at a slower rate than low-priced units in the 1980 s.

All of these studies offer explanations for the patterns that they observe, but the analyses are thin. Smith and Tesarek, for example, talk about sharp reductions in "entrepreneurial and professional income" in Houston and point out that "immigrants to Houston dominated the new home market," but present no data nor any model to link their stories to the observed pattern of price changes. Case and Shiller (1994) have more disaggregated data to support their arguments, but their analysis is simply a series of supply and demand scenarios that might explain the California/Boston differences: for example, California had more immigrants (low-end demand) while Boston had more low-end supply at the end of the boom. While both Mayer and Poterba look for 
evidence to support more specific hypotheses (tax-induced changes in user costs differing by price tier, and a liquidity constraint model), their focus is narrow, and they ultimately open up more questions than they answer.

Recently available data on home price changes by town over a 13-year period in Eastern Massachusetts show even more interesting patterns of price movements and make possible a much more exhaustive analysis of the underlying causes. The data for Massachusetts show, for example, that homes in high-end suburbs close to Boston such as Newton and Brookline have recently rebounded sharply, with current prices above their 1989 peaks, while homes in more distant industrial areas such as Brockton and Lowell remain well below their peak values. In fact, during the boom period, appreciation by town varied between 141 and 250 percent, while price declines during the bust varied between 9 and 25 percent. Using the town as the unit of analysis provides the opportunity to take the analysis to a higher level and simultaneously test a number of competing hypotheses about these patterns of price change.

This paper begins with a simple model of price determination in a metropolitan housing market with a number of spatially fixed submarkets, each with its own set of amenities and locational characteristics. Using the model as a framework, the paper identifies several categories of town characteristics that might be expected to determine cross-jurisdictional patterns of housing and land prices over time. Finally, the paper empirically explores price movements over the cycle (1982 to 1992) with data on the characteristics of 168 separate Massachusetts jurisdictions.

The results are consistent with many of the predictions of a standard urban model in which the price surface is determined by a set of locational attributes and amenities. In particular, employment patterns, accessibility, 
school quality, and housing supply shocks had effects on the pattern of price changes across cities and towns between 1982 and 1992.

\section{The Framework}

Before turning to the data, it is important to have a framework for thinking about prices and price changes across jurisdictional submarkets in a metropolitan housing market. A standard model of intra-metropolitan housing markets assumes that a predetermined number of households shop for housing across a set number of jurisdictions. Each jurisdiction has a fixed amount of land. Households derive utility from consuming housing $(H)$, an amenity $(A)$ associated with locating in the jurisdiction (a public good), and a composite commodity $(X)$. Household income is assumed to be fixed across the set of jurisdictions, but a pecuniary tax (which could be positive or negative) varies by jurisdiction.

Housing is produced by competitive suppliers using capital and land that are substitutable, and both the composite good, $X$, and capital are in perfectly elastic supply from a national market. Households are assumed to be mobile across jurisdictions within the "metropolitan area," but the total metropolitan area population is assumed to be fixed.

If production and utility functions are convex and exhibit constant returns, it can be shown that such a model yields a unique set of equilibrium land prices and housing prices across the jurisdictions. ${ }^{1}$ Households move until prices and quantities of each variable equate utility across jurisdictions. The results include land price, housing price, and density

'Case and Grant (1991) present an explicit version of this model and solve it for specific values of land and housing prices across a set of 25 jurisdictions. A different version is proposed by Haurin (1980). 
"gradients." Equilibrium prices and densities are a function of the values of $A_{j}, y, t_{j}$, and $L_{j}$ for all jurisdictions as well as the shape of the utility and production functions, where:

$A_{j}=a$ vector of amenities at jurisdiction $j$, which are public goods to residents

$y=$ per household income

$t_{j}=$ per household tax at location $j$

$L_{j}=$ the amount of (developed) 1 and in jurisdiction $j$.

Changes in any of the values of $A_{j}, y, t_{j}, L_{j}$ will result in a new set of equilibrium land and housing prices across jurisdictions. Specifically, if we derive a reduced-form equation for equilibrium housing price at a particular location $j$,

$$
\begin{aligned}
& P_{j}^{h}=P\left(A_{1} \ldots A_{j}, y, t_{1} \ldots t_{j}, L_{1} \ldots L_{N}\right) \text {, where } \\
& P_{j}^{h}=\text { price of housing services in jurisdiction } j .
\end{aligned}
$$

The following relationships can be derived from the reduced-form equation:

$$
\begin{aligned}
& d P_{j}^{h} / d A_{j}>0, \\
& d P_{j}^{h} / d t_{j}<0, \\
& d P_{j}^{h} / d L_{j}<0, \text { and } \\
& d P_{j}^{h} / d y>0 .
\end{aligned}
$$

For purposes of empirical work, changes in amenity, changes in the tax variables, and changes in the amount of 1 and in each jurisdiction all have predictable effects on housing prices in the model.

\section{Categories of Variables for Empirical Analysis}

The simple model presented above provides a framework for analyzing the cross-jurisdictional pattern of housing and land prices over time. This 
section will bridge that model to the empirical work by identifying several categories of variables (entering through the amenity or tax/bonus concept discussed above) that might be expected to change the equilibrium price surface across towns.

Shifts in Patterns of Employment

A shift in either the sectoral mix of employment in a metropolitan area or a simple change in the location of employment can affect the pattern of housing prices across submarkets. For example, if the employment nodes most accessible to a town lose jobs, then that town becomes less desirable and real estate prices fall. In the context of the model, this may be seen either as a change in amenity or a change in pecuniary costs associated with living in a particular town. That is, less accessibility and higher transport cost could be thought of as entering through $A_{j}$ (time cost and disutility) and through budget constraints as an increase in $t_{j}$ (pecuniary costs).

Movements in the sectoral mix of jobs can change relative house prices within a metropolitan area because specific sectors concentrate in different towns. Communities located on the perimeter of the Boston metropolitan area, such as Lawrence, Lowe11, Brockton, Fitchburg, and Leominster, have concentrations of manufacturing employment, while downtown Boston is dominated by services and FIRE (finance, insurance, and real estate) sector jobs. In equilibrium, workers locate near their jobs, so those towns with high concentrations of manufacturing workers tend to be near concentrations of manufacturing jobs. When manufacturing employment declines, however, property values in towns with high initial concentrations of manufacturing workers may fall because such towns have become less accessible to the locations of the 
new jobs..$^{2}$ In this paper, we use the initial mix of jobs for a town's residents as a proxy for such job locational characteristics, which are difficult to measure directly.

Alternatively, movements in the sectoral mix of jobs could affect the relative house prices across towns owing to changes in the income of town residents. For example, displaced manufacturing workers may be forced to take lower-paying services jobs, thus reducing their demand for housing.

Note that the relationship between changes in home prices and changes in the sectoral mix of residents is complex because the response of workers to changes in the job mix is endogenous. For example, consider a town with many manufacturing workers when manufacturing employment falls. Some of these workers will switch to less accessible service sector jobs, others will change their place of residence, and some will remain unemployed. As some former manufacturing workers move away, house prices in the town will fall, making that town relatively more attractive to services workers living elsewhere who are willing to trade off lower house prices against a longer commute. Thus, falling home prices may be associated with increases or decreases in the percentage of local residents employed in services, depending on the number of local residents who take services jobs and the net in-migration of services workers.

${ }^{2}$ This discussion assumes that the shift from manufacturing to services employment is not attributable to differences in intra-metropolitan area costs, but rather to exogenous factors such as an increase in the relative productivity of the manufacturing sector, an increase in the share of manufacturing imports, or a decrease in the relative price of manufactured goods. 


\section{Accessibility to Boston}

Accessibility to the central city is valuable, both as an amenity and because of the importance of the downtown as an employment center. Many households travel to the city frequently to enjoy the theater, professional sports, restaurants, and so forth. Most residents occasionally travel by air or train and must be able to get to Logan Airport or South Station. In addition, the central city contains some 50 million square feet of office space, and the metro area is the fifth largest office market in the United States. Thus, accessibility to Boston is accessibility to jobs. Because office-based (services and FIRE) employment has been increasing, accessibility to Boston should be associated with rising relative property values. Similarly, if theater performances, restaurant meals, and sporting events are luxury goods, households should be willing to pay increasing amounts for accessibility during periods of rising incomes.

\section{Supply Shocks}

The initial pattern of home prices across jurisdictions should reflect expectations about the availability of developable land and likely changes in the number and character of housing units over time. But supply shocks can and do occur. Indeed, during the peak of the building cycle in Eastern Massachusetts, housing starts throughout the metropolitan area were triple the level of absorption (Case 1991). Clearly this excess supply was not uniformly distributed, and it was not fully anticipated. Much of the new development was on previously undeveloped land and, in the framework of the above model, could be thought of as an unanticipated increase in $L_{j}$, and $d P_{j}^{h} / d_{j}<0 .{ }^{3}$

${ }^{3}$ Because the solution to the model allocates all of $L_{j}$ to housing, solving the model with a higher $L_{j}$ is exactly like adding new $l$ and and developing it with housing. 
Thus, unexpected increases in the available supply of housing should reduce relative house prices.

\section{Demographics}

Over time, the age distribution of the population determines aggregate household formation rates. Increases in the number of households (holding total population constant) will tend to push property values up, as will population increases from in-migration. But the cross-jurisdictional pattern of demand and price effects of demographic change depends on the mix of new households. An increased number of new households with very low incomes will have little impact on high-end suburban property values, while new high-tech executives coming from California will have little impact on lower-income communities like Lowell or Chelsea.

The initial demographic mix of a town may be thought of as an indicator of certain amenities that are attractive to particular demographic groups. That is, residents with children might prefer to live in a town with other similar families. Towns with a high fraction of families with children might offer amenities that are relatively more valuable to families, such as good schools and town-sponsored day-care and after-school programs, which are difficult to measure directly. During the $1980 \mathrm{~s}$, the baby-boom generation reached child-bearing age. To the extent that baby-boomers prefer to live in towns with other households in their age group, house prices in towns with a concentration of middle-aged residents should have been expected to increase relative to towns with younger residents.

Note that perfect foresight or highly responsive town services could counteract any impact of the baby-boom generation on cross-sectional house prices. Since the baby boom movement into middle age could be easily 
forecast, an efficient houșing market would cause prices in towns that appeal to baby-boomers to have risen in previous periods in anticipation of babyboomers entering the housing market. Alternatively, if other towns could easily replicate the services demanded by baby-boomers, competition among towns would mitigate any relative price changes.

other Amenities

Both the level of and changes in amenities can have an impact on price appreciation. Assuming the amenity yields positive utility, we have shown that $d P_{j}^{h} / d A_{j}>0$. An exogenous drop in a locality's crime rate, for example, should raise housing demand and increase local property values relative to property values in competing jurisdictions that do not experience a decrease in crime. ${ }^{4}$

Moreover, even though amenities such as local public school quality are capitalized into prices at a given moment, they may interact with income or demographics over time. Thus, the impact of changes in these variables on prices could depend on the level of amenity. The most obvious example is that if the number of children of school age changes, schooling may become more or less important to home buyers. Both the proportion of households with no children and the number of children per household could affect the demand for housing and, thus, prices across towns. A household with two school-age children would presumably be willing to pay more for housing in towns with good schools than identical households with one child. A household with no

\footnotetext{
${ }^{4}$ In general, prices and amenities are endogenous. For example, an exogenous increase in a town's house prices (caused by improved transportation access) might lead to an in-migration of higher-income households who commit fewer crimes, reducing the town's crime rate. The endogeneity of house prices and amenities creates empirical difficulties because instruments for amenities are difficult to find.
} 
children would presumably not be willing to pay a premium for good schools, holding taxes and expected resale value constant. Indeed, as we will discuss below, the number of school-age children dropped dramatically in Massachusetts during the $1980 \mathrm{~s}$, with a significant impact on the pattern of housing values.

In addition, during the 1984-88 Massachusetts boom, incomes rose at very rapid rates. Because households demand amenities in the model and different amenities may have different income elasticities of demand, a shift in income may lead to patterns of demand and price change related to the particular packages of amenities offered across towns. This model assumes that towns cannot quickly and costlessly replicate such amenities.

\section{Immigration}

During the mid 1980s, the Boston area experienced a significant increase in Cambodian and Vietnamese immigrants. If the immigrants had median incomes, immigration would increase demand for housing in those towns, and thus should have led to higher prices for owner-occupied housing. Alternatively, if the new immigrants were poor and placed additional burdens on town resources, immigration could have led to an increase in taxes or a decrease in public sector services to other residents within a town and thus to lower property values.

\section{$\underline{\text { Taxes }}$}

While the package of public services offered to residents of a particular town enters the model as a component of the amenity vector, $A_{j}$, local taxes enter budget constraints through $t_{j}$. Taxes on residential property depend on both the level of public services and the commercial and/or industrial base in the town. Thus, taxes on residential property and public services may vary independently across towns. If residential property taxes 
rise while public service levels are held constant, property values would be expected to fall and vice versa. In addition, the level of property tax rates may be a proxy for public service levels that are not fully controlled for. Like demand for any other amenity, public service demand may vary over time with changes in income or demographics.

\section{The Data: Home Prices in Massachusetts: 1982 to 1992}

The indexes presented in this article were estimated using a variation on the weighted repeat sales methodology first presented in Case and Shiller (1987). The method uses arithmetic weighting proposed by Shiller (1991) and is based on data on recorded sales of all properties that pass through the market more than once during the period. The Massachusetts file contains over 135,000 pairs of sales drawn between 1981 and March 1994. First, an aggregate index was calculated based on all recorded sale pairs. Next, indexes were calculated for individual jurisdictions. In Eastern Massachusetts, indexes were estimated for 168 cities and towns.

\section{Aggregate Indexes}

Table 1 presents data based on the aggregate real indexes for Boston. Between the first quarter of 1982 and the first quarter of 1983, nominal house prices rose slightly above the rate of increase of consumer prices. But by the beginning of 1984, real house prices began to accelerate rapidly, up 15 percent in a year and more than 115 percent in five years. The peak was relatively long-lived, with nominal prices remaining essentially unchanged but real prices falling with general inflation from second quarter 1987 through first quarter 1990, nearly three years. Once prices started falling, they 
dropped quickly, but not nearly so far as they had risen. Overall, the peak to trough decline in Boston was 27 percent.

\section{Town Data}

The remainder of this paper focuses on house price changes in individual cities and towns. While other papers have disaggregated metropolitan area price indexes into tiers by home price or quality, ${ }^{5}$ changes in home prices in the underlying individual cities and towns are likely largely responsible for differences in appreciation rates by tier.

Table 2 presents summary statistics for 168 separate Massachusetts city and town price indexes. ${ }^{6}$ On a town basis, the overall mean increase from 1982 through the market peak was 119 percent in real terms with a standard deviation of 13.1 percent. The mean decline from peak to trough was 25.1 percent with a standard deviation of 5.3 percent. Homes in the town with the highest overall increase appreciated 178 percent in real terms, while homes in the town with the smallest increase appreciated 92 percent. The largest decline from peak was 33 percent; the smallest was 19 percent. When communities are divided into four groups based on real price appreciation, the quartile mean price changes from lowest to highest were 103 percent, 112 percent, 121 percent, and 140 percent. $^{7}$ In the bust, quartile mean price declines were 21.5 percent, 23.8 percent, 26.3 percent, and 28.9 percent.

${ }^{5}$ See Case and Shiller (1994), Mayer (1993), Poterba (1991), and Smith and Tesarek (1991) as examples.

${ }^{6}$ Massachusetts is made up of a total of 351 cities and towns that cover 100 percent of the State's land area. Indexes were constructed for all towns (168) with a sufficient number of sale pairs to permit estimation of wellbehaved price indexes. periods.

7Quartile divisions are computed separately for the boom and bust 
Map 1 shows the location of towns that are included in the sample and divides them into the quartiles listed above. As is clear from the map, differences in appreciation rates are not randomly distributed across the Boston area. Towns with the greatest appreciation rates are clustered around Boston and on the South Shore. ${ }^{8}$ Towns located west of Boston, but still in the metropolitan area, had the lowest rates of appreciation.

\section{Town Characteristics}

Table 3 summarizes the data used in this paper. ${ }^{9}$ Apart from the price indexes described earlier, most information about towns comes from the 1980 and 1990 Censuses (exceptions are noted below). Data for the key years 1982 (trough), 1988 (peak), and 1992 (trough) would better capture changes in towns over the economic cycle, but they are not available.

School and crime data come from various Massachusetts state government departments and are available for selected years after 1980 . Town-level housing permits come from the U.S. Department of Commerce and are available on an annual basis. Land use data are from the University of Massachusetts and include total number of acres that are undeveloped or devoted to public uses as of 1984. Except for crime statistics, all the data used in the analysis are available for all 168 towns in eastern Massachusetts. The crime data are reported only for larger towns, which generally have higher crime rates.

A comparison of the 1980 and 1990 Census data shows considerable economic change over 10 years. Most obviously, the percentage of workers employed in the manufacturing sector declined from 32 to 23 percent. While

${ }^{8}$ Boston is located in the middle of the eastern shore of Massachusetts.

${ }^{9}$ Because most homeowners consider real estate price changes in nominal terms, we use nominal prices to establish peak and trough dates for each town. 
real income rose by over one-third, school spending per weighted pupil increased even more. ${ }^{10}$ Reported crime rates actually declined. The percentage of the population in the middle-age years (age 35 to 60) also increased during the decade as the first 10 years of the baby boom generation passed the 35-year-old threshold.

\section{Empirical Results}

Table 4 presents regression results for the main variables discussed in Section 3. In columns 1 , the change in prices over the entire cycle (1982-totrough) is regressed on the 1980 share of residents who work in the manufacturing or service sector, the 1980 share of residents between age 35 and 60 , the number of housing permits issued between 1982 and 1992, distance from Boston and its square, and the 1980 levels of town amenities (i.e., school spending per weighted pupil, school achievement test scores and crime rates), the residential tax rate, and median single-family house value and its square. Endogeneity is a potential problem for the new construction variable (housing permits), so the regressions are run with two-stage least squares, using lagged permits and the amount of vacant land as instruments, and two specifications are presented.

The regression results show that the 1980 employment base and demography are statistically significant in explaining the cross-sectional variation in prices across towns. The coefficient on the manufacturing variable is negative and significantly different from zero at the 1 percent level in

\footnotetext{
${ }^{10}$ The weighted pupil count is reported by the Massachusetts Department of Education and reflects estimates of the additional cost of educating students who have special needs, or whose families are below the poverty line or do not speak English as a first language. Dividing school spending by weighted pupils yields a per-pupil spending estimate that is adjusted for such costs.
} 
column 1. Towns with a larger share of residents working in the manufacturing sector enjoyed less of an increase in house values over the boom-bust cycle. Using the 1980 employment of town residents as a proxy for the types of jobs that are located near the town, the results suggest that house prices in towns located closer to declining manufacturing employment nodes fell because locational amenities, like accessibility to manufacturing employment, became less valuable as the importance of manufacturing in the economy relative to services shrank. ${ }^{11}$

The coefficient on school test scores was significant and negative, indicating that homes in high-quality school districts appreciated less than homes in lower-quality school districts. ${ }^{12}$ Assuming that homes in good school districts command a premium over homes in lesser school districts, ceteris paribus, those premiums apparently dropped between 1982 and 1992 . The cause was a large decrease in the aggregate demand for the amenity: enrollment in public elementary and secondary schools $(K-12)$ in Massachusetts dropped by 18.4 percent between 1980 and 1990, while enrollments in Massachusetts public high schools declined an astounding 34 percent. $^{13}$

${ }^{11}$ In other regressions, separate dummy variables were included for towns bordering on Routes 128 and 495, because services firms tended to be located on Route 128, while manufacturing firms were more likely to be located near Route 495 . Neither of the coefficients is significantly different from zero.

${ }^{12}$ School test scores reflect community and parental characteristics as well as the value-added of a school system. Also, given that earliest available test scores were from 1988, the relative rank of schools between 1982 and 1988 is assumed to be constant. Other regressions substituted a variable for school spending per weighted pupil instead of test scores, but the coefficient on that variables was almost always insignificantly different from zero.

${ }^{13}$ Both the drop in overall enrollments and the drop in high school enrollments are the largest among the 50 states by an order of magnitude. The state with the second largest decline in public secondary school enrollments during the same period was Connecticut with a 27 percent drop. All enrollment 
The positive and significant coefficient on the 1980 percentage of town residents aged 35 to 60 indicates that house prices appreciated faster in towns with a larger 1980 percentage of middle-aged residents, all other things equal. As with the manufacturing estimates, the empirical magnitude is modest; a one-standard-deviation increase in the 1980 percentage of a town's residents aged 35 to 60 was associated with a 3.7 percent greater increase in that town's house prices. The age-mix variable may be a proxy for town amenities and services that are attractive to middle-aged persons, whose number increased during the 1980 s as the baby-boomers aged. Alternatively, middle-aged persons might prefer to live with others of the same age, so the positive age-mix coefficient could represent a clustering effect.

The negative and significant coefficient on the number of single-family housing permits issued between 1982 and 1992 is consistent with the hypothesis that expectations of new construction were not fully capitalized into house prices. Given that New England's population was growing at a rate well below the U.S. average, few observers could have anticipated that residential permits would be issued at a rate that was well above the national average during the boom. Thus, relative house prices apparently fell in towns that allowed greater than anticipated construction activity.

Distance to Boston was also associated with the pattern of price changes. The coefficients on the linear and quadratic terms indicate that house prices increased at a greater rate, the closer a town was to Boston. For example, house prices grew 5.1 percent faster for a town that is located one standard deviation closer to Boston than average town in the sample (15.4

data from the U.S. Bureau of the Census, Statistical Abstract of the United States, 1994, Table 242 and from the U.S. Department of Education, Digest of Education Statistics, 1988 and 1993. 
miles versus 31.5 miles). ${ }^{14}$ One possibility is that services jobs in downtown Boston grew at a faster rate than people had anticipated in 1982, although the equation controls separately for the 1980 employment mix of a town's residents. Alternatively, proximity to Boston's amenities (entertainment and transportation services) may have become more valuable with the rise in real household income.

Finally, the regression includes the 1980 median owner-occupied singlefamily house value and its square. The coefficients on both of these variables are significantly different from zero with 95 percent confidence and suggest that housing price appreciation was greatest in the initially lowpriced towns. For example, house prices in a town whose 1980 median price was one standard deviation below the sample mean grew 10 percent more than prices in a town at the sample mean. One possible explanation is that the housing market was out of equilibrium at the beginning of the sample period. In addition, the results are consistent with the hypothesis that the large rise in real housing prices (combined with lending limits in the mortgage market) caused many first-time buyers to search for a house in more affordable lowerpriced communities, thus adding additional (unanticipated) pressure on house prices in those towns.

\footnotetext{
${ }^{14}$ The point of minimum appreciation occured at 101.7 miles, while the maximum distance from Boston in the sample was $118 \mathrm{miles.} \mathrm{In} \mathrm{effect,} \mathrm{towns}$ located further than 100 miles from Boston could be considered to be out of the Boston area and thus the subsequent arguments about accessibility to Boston's amenities and employment base probably do no hold for these towns. The largest direct impact of distance from Boston on subsequent house price appreciation occurs for towns located much closer to Boston.
} 


\section{House Prices and Changes in Income}

We have suggested that the correlation between the initial sectoral distribution of jobs and subsequent house price changes may be caused by changes in the value of specific locations within the metropolitan area. An alternative hypothesis is that the changes in a town's house prices may be related more directly to the change in incomes of workers in specific sectors who live in that town. To test this alternative directly, house price changes were regressed on the same regressors as in Table 4, plus the change in town median household income between 1980 and 1990. Because of the endogeneity of changes in median house prices and incomes, that regression included the percent of residents with a college degree in 1980 as an instrument for changes in income. ${ }^{15}$

The empirical results (available from the authors) did not support the income hypothesis posited above--instead, changes in town household income were negatively related to changes in town house prices. Also, the coefficients for the 1980 median house value and its square and the 1980 share of persons between 35 and 60 years old were no longer statistically significantly different from zero when income was included. These differences suggest that the change in income variable is positively correlated with house values and the percentage of 35- to 60-year-olds. Household income was not included in the baseline regressions (Table 4) because the standard urban

\footnotetext{
${ }^{15}$ See Freeman and Katz (1993) for evidence that returns to education increased during the 1980 s.
} 
model presented earlier predicts that income changes across towns in response to changes in house prices and amenities. ${ }^{16}$

\section{The Boom and Bust}

Sectoral employment, demographics, and supply shifts had important effects on the distribution of house price changes over the whole cycle. Also of interest is whether these effects were the same in the boom and bust periods. If not, differences between the boom and bust periods would suggest that expectations about the future course of housing prices changed between 1982 and 1992. For example, if the impact of permits issued on house prices was caused by an unexpected increase in new construction during the boom, then the coefficient on new permits issued should be negative and significant during the boom and near zero during the subsequent bust. Similarly, the decline in manufacturing employment might have surprised observers in 1982 , but that trend was clearly apparent by 1988. Also, differences in appreciation rates for low-priced and high-priced towns between the boom and the bust provide the opportunity for a rudimentary test of the liquidity constraint model first proposed by Stein (1993). In that model Stein suggests that trade-up buyers are quite responsive to changes in house prices over the real estate cycle because existing homeowners need to sell their current home

\footnotetext{
${ }^{16}$ The standard urban model also predicts that immigration can affect the cross-sectional distribution of house prices. The predicted sign on the coefficient for the change in Asian population is uncertain, depending on whether immigrants consume net additional city services (negative coefficient) or provide additional demand for owner-occupied housing (positive coefficient). A negative coefficient was found for the change in a town's Asian population, showing that an increase in the percentage of Asian residents was associated with slower than average growth in house prices, which should not be surprising given that most of the Asian immigrants were poor and thus did not participate in the market for owner-occupied housing.
} 
in order to generate enough cash to make a down payment on a new property. One implication of the Stein model is that prices of high-priced homes (purchased primarily by trade-up buyers) should have a greater variance over the real estate cycle than the prices of low-priced units. In the context of this article, the liquidity constraint model predicts that home prices in high-priced towns would both appreciate faster during the boom and decline faster during the bust.

Columns 2-3 in Table 4 present the baseline regressions for the boom and bust sub-periods. Because the dependent variable in both tables is the full 1982-to-peak or peak-to-trough change in price by town and the boom 16.5 years) lasted more than twice as long as the bust ( 3 years), the coefficients for the boom period (columns 3-4) are larger in magnitude than for the bust (columns 5-6). Dividing the boom and bust coefficients by the number of years each lasted suggests that the impacts of manufacturing in the employment base, demographics, and supply on house prices were larger in magnitude during the boom, but did not disappear during the bust, when one might expect these factors to have been incorporated into expectations. Distance from Boston al so had a consistent impact on price changes during the boom and the bust, with house prices declining in relative terms the farther a town is located from Boston. ${ }^{17}$

To test more rigorously the differences in these coefficients between the boom and bust periods, we combined the two subsample regressions into a single equation with the annualized price change as the dependent variable (results not shown). Statistical tests failed to reject the joint hypothesis

\footnotetext{
${ }^{17}$ Even though the individual coefficients on miles from Boston and its square in Table 7 are insignificant, the joint hypothes is that both coefficients equal zero can be rejected with 95 percent confidence.
} 
that the coefficients for the manufacturing, demographics, and housing permits variables were different during the boom and bust periods, as we11 as the individual hypotheses that each of the coefficients differed during the two sub-periods. ${ }^{18}$ The similarity between the boom and bust coefficients suggests that changes in expectations alone cannot explain the impact of shifts in manufacturing and construction.

The coefficients on measures of school quality, the crime rate, and the 1980 median value and its square change markedly between the boom and bust regressions. In particular, housing values in low-priced towns appreciated at above average rates up to the middle of 1988, but fell more quickly after that time. This evidence runs counter to the predictions of the liquidity constraints model. The coefficient on schoolassessment test scores is negative and significantly different from zero during the boom when public school enrollments were falling dramatically, but insignificant during the bust when enrollments stabilized. Finally, house prices in high crime rate towns appreciated faster in the boom, but remained similar to other towns in the bust.

\section{Conclusion}

The results of this paper are consistent with many of the predictions of a standard urban model in which towns have a fixed set of locational attributes and amenities. In particular, evidence from the Boston metropolitan area suggests that house prices in towns with a large share of residents working in the manufacturing sector in 1980 grew less quickly in the

\footnotetext{
${ }^{18}$ The p-value for the joint test is 0.88 , while the individual hypotheses have p-values that are greater than 0.55 .
} 
ensuing years when aggregate manufacturing employment fell. As baby boomers moved into middle age, house values appreciated faster in towns with a larger initial percentage of middle-aged residents. Housing values rose more slowly in towns that allowed additional construction, and values rose faster in towns closer to Boston. Finally, as fewer families had children who attended public schools statewide, the price premium associated with housing in towns with good schools fell.

A11 of these findings support the view that towns are not perfect substitutes for each other, even within a metropolitan area, and that town amenities and public services are not easily replicated or quickly adaptable to shifts in demand. Marketwide shifts in the employment base or demographics can have significant housing market implications. For example, an area with a large number of small houses and condominiums does not have as much appeal to 35- to 45-year-old buyers, who have become more numerous as the baby boomers age. Similarly, school quality is very difficult to change in a few years. Even though it is difficult to change town characteristics in the short run, the empirical estimates imply only modest differences in appreciation rates as a result of these aggregate changes in employment or demographics. For example, with an average total appreciation of 132 percent over the cycle, house prices appreciated by a total of 6 percentage points less in a town with a 1980 share of manufacturing workers that is one standard deviation above the mean. The impact of a change in demographics on cross-sectional appreciation rates was even more modest (less than a total of 4 percentage points higher for towns whose 1980 percentage of older residents was one standard deviation from the mean). Expectations clearly play a role in the housing market, but the stability of some of the coefficients between boom and bust periods 
suggests that the housing market did not fully incorporate all available information.

Future research should focus on validating these conclusions for other metropolitan areas, although the aggregate shocks will be different depending on the city and time period chosen. In addition, the role of expectations could be more fully explored by finding cases in which shifts in crosssectional demand are not anticipated (for example, a natural disaster or an unexpected court decision that changes development rights in some communities). Finally, researchers might further explore the role of sectoral industry shifts, by using data on the location of jobs within a metropolitan area. 


\section{$\underline{\text { References }}$}

Case, Karl E. 1991. "The Real Estate Cycle and the Economy: Consequences of the Massachusetts Boom in 1984-87." New England Economic Review, September/October, pp. 37-46.

Case, Karl E. and James H. Grant. 1991. "Property Tax Incidence in a Multijurisdictional Neoclassical Model." Public Finance Quarterly, vol. 19, no. 7, October, pp. 379-92

Case, Karl E. and Robert J. Shiller. 1987. "Prices of Single-Family Homes since 1970: New Indexes for Four Cities." New England Economic Review, September/0ctober, pp. 45-56.

Case, Karl E. and Robert J. Shiller. 1994. "A Decade of Boom and Bust in the Prices of Single-Family Homes: Boston and Los Angeles, 1983 to 1993." New England Economic Review, March/Apri1, pp. 40-51.

Freeman, Richard B. and Lawrence F. Katz. 1993. "Rising Wage Inequality: The United States vs. Other Advanced Countries." In Richard B. Freeman, ed., Working Under Different Rules. New York: Russell Sage Foundation.

Haurin, Donald. 1980. "The Regional Distribution of Population, Migration, and Climate." The Quarterly Journal of Economics, September, pp. 293-308.

Mayer, Christopher J. 1993. "Taxes, Income Distribution, and the Real Estate Cycle: Why All Houses Do Not Appreciate at the Same Rate." New England Economic Review, May/June, pp. 39-50.

Poterba, James M. 1991. "House Price Dynamics: The Role of Tax Policy and Demography." Brookings Papers on Economic Activity 2, pp. 143-183.

Shiller, Robert J. 1991. "Arithmetic Repeat Sales Price Estimators." Journal of Housing Economics, vol. 1, no. 1 (March), pp. 110-126.

Smith, Barton A. and William P. Tesarek. 1991. "House Prices and Regional Real Estate Cycles: Market Adjustments in Houston." AREUEA Journal, vol. 19, no. 3, pp. 396-416.

Stein, Jeremy. 1993. "Prices and Trading Volume in the Housing Market: A Model with Downpayment Constraints." NBER Working Paper, no. 4373, March.

White, Harold. 1980. "A Heteroskedasticity-Consistent Covariance Matrix Estimator and a Direct Test for Heteroskedasticity." Econometrica, vol. 50, pp. 483-99. 
Table 1

Changes in Real Prices of Single-Family Homes in Boston, 1982 to 1994

\begin{tabular}{|c|c|c|}
\hline Period & $\begin{array}{l}\text { Change in } \\
\text { Real Prices }\end{array}$ & \\
\hline $1982:$ I to $1983: I$ & 2.4 & \\
\hline 1983:I to $1984: I$ & 15.0 & \\
\hline $1984:$ I to $1985: I$ & 22.8 & \\
\hline $1985:$ I to $1986: I$ & 32.8 & \\
\hline 1986: I to $1987: I$ & 10.8 & \\
\hline $1987:$ I to $1988: I$ & 2.0 & \\
\hline 1988: I to $1989: I$ & -3.6 & \\
\hline 1989:I to 1990:I & -8.3 & \\
\hline 1990:I to $1991: I$ & -15.2 & \\
\hline 1991:I to 1992:I & -2.0 & \\
\hline 1992: I to 1993:I & -0.4 & \\
\hline 1993: I to 1994:I & +0.3 & \\
\hline \multicolumn{3}{|c|}{ Overall Increase (Boom) } \\
\hline $\begin{array}{l}\text { Boston } \\
\text { 1983:I to 1988:III }\end{array}$ & 115.7 & \\
\hline \multicolumn{3}{|c|}{ Overall Decrease (Bust) } \\
\hline $\begin{array}{l}\text { Boston } \\
\quad \text { 1988: III to 1991:I }\end{array}$ & -27.0 & \\
\hline \multicolumn{3}{|l|}{ Overall Change } \\
\hline 1983: I to 1994:IV & 54.3 & \\
\hline
\end{tabular}

Source: Case Shiller and Weiss Inc. 
Table 2

Massachusetts Town Data, 1982 to 1992

$N=168$

Peak-Trough

Overall Mean Change (percent)

119.2

$-25.1$

Standard Deviation

13.1

5.3

Coefficient of Variation .11 .21

Mean Change: Lowest Quartile Price Change

103.4 $-21.5$

Mean Change: 2nd Quartile Price Change

112.1 $-23.8$

Mean Change: 3rd Quartile Price Change

121.0 $-26.3$

Mean Change: Highest Quartile Price Change

140.1 $-28.9$

Lowest Change

Highest Change

92.3

178.3

$-19.4$

$-33.0$

Note: Quartiles are computed separately for the boom and bust periods and are in real terms. The index values for the peak and trough are computed separately for each town, and correspond to the date of each town's respective peak and trough.

Source: Case Shiller and Weiss Inc. 


\begin{tabular}{|c|c|c|c|c|}
\hline & Mean & $\begin{array}{l}\text { Standard } \\
\text { Deviation }\end{array}$ & Minimum & Maximum \\
\hline Nominal Price Change: 1982-Peak' & 1.73 & .19 & 1.41 & 2.49 \\
\hline Real Price Change: 1982-Peak' & 1.19 & .13 & .92 & -.33 \\
\hline Nominal Price Change: Peak-Trough' & -.16 & .03 & -.25 & -.1 \\
\hline Real Price Change: Peak-Trough' & -.25 & .05 & -.33 & -.19 \\
\hline Nominal Price Change: 1982-Trough' & 1.32 & .17 & .96 & 1.84 \\
\hline Real Price Change: 1982-Trough' & .64 & .13 & .39 & 1.18 \\
\hline Miles from Boston & 31.5 & 16.1 & 0 & 118 \\
\hline Acres Open and Public Land $(1984)^{2}$ & 2,791 & 1,692 & 94 & 13,272 \\
\hline
\end{tabular}

1980 Census Data for Town Residents (except as noted)

\begin{tabular}{|c|c|c|c|c|}
\hline $\begin{array}{l}\text { Fraction of Residents Horking in } \\
\text { Manufacturing }\end{array}$ & .32 & .10 & .11 & .56 \\
\hline Fraction of Residents Working in Services & .34 & .08 & .20 & .62 \\
\hline Fraction of Residents 35 to 60 Years old & .28 & .04 & .20 & .40 \\
\hline Housing Permits per 1,000 Housing Units ${ }^{3}$ & 7.3 & 7.1 & 0 & 40.4 \\
\hline School Spending per Weighted Pupil“ & 1,837 & 332 & 1,049 & 3,255 \\
\hline Median single-Fanily House Value (Thousands & 5) 56 & 19 & 33 & 144 \\
\hline Median Household Income (Thousands) & 21.7 & 5.8 & 11.5 & 47.6 \\
\hline Fraction of Residents of Asian Descent & .006 & .006 & 0 & .036 \\
\hline $\begin{array}{l}\text { Fraction of Adult Residents with a College } \\
\text { Education }\end{array}$ & .21 & .12 & 0.05 & .60 \\
\hline Crimes per Resident ${ }^{5}$ & .042 & .019 & .010 & .135 \\
\hline Effective Residential Tax Rate & .028 & .007 & .012 & .063 \\
\hline
\end{tabular}

1990 Census Data for Town Residents (except as noted)

\begin{tabular}{|c|c|c|c|c|}
\hline $\begin{array}{l}\text { Fraction of Residents Horking in } \\
\text { Manufacturing }\end{array}$ & .23 & .07 & .09 & .42 \\
\hline Fraction of Residents Working in Services & .40 & .07 & .28 & .68 \\
\hline Fraction of Population 35 to 60 Years Old & .32 & .04 & .23 & .47 \\
\hline Housing Permits per 1,000 Housing Units & 7.9 & 6.0 & 0 & 27.8 \\
\hline School Spending per Weighted Pupil $(1992)^{4} 4$ & 4,198 & 989 & 2,059 & 7,656 \\
\hline $\begin{array}{l}\text { School Spending per Heighted Pupil } \\
\text { (1992; in } 1980 \text { Dollars) }\end{array}$ & 2,645 & 623 & 1,297 & 4,824 \\
\hline Median single-Family House Value (Thousands) & 185 & 61 & 112 & 498 \\
\hline $\begin{array}{l}\text { Median Single-family House Value (Thousands } \\
\text { of } 1980 \text { Dollars) }\end{array}$ & 116 & 38 & 56 & 314 \\
\hline Median Household Income (Thousands) & 46.5 & 13.1 & 22.2 & 95.1 \\
\hline $\begin{array}{l}\text { Median Household Income (Thousands of } \\
1980 \text { Dollars) }\end{array}$ & 29.1 & 8.2 & 13.9 & 59.9 \\
\hline Fraction of Residents of Asian Descent & .015 & .016 & .002 & .109 \\
\hline $\begin{array}{l}\text { Fraction of Adult Residents with a College } \\
\text { Education }\end{array}$ & .28 & .14 & .08 & .65 \\
\hline Crimes per Resident ${ }^{5}$ & .031 & .021 & .003 & .109 \\
\hline Effective Residential Tax Rate (1992) & .012 & .002 & .007 & .017 \\
\hline
\end{tabular}

Note: The index values for the peak and trough are computed separately for each town, and correspond to the date of each tow's respective peak and trough.

'Source: Case, Shiller, and Heiss, Inc.

'Source: University of Massachusetts.

source: U.S. Department of Commerce.

Source: Massachusetts Department of Education

source: Massachusetts Department of State Police.

'Source: Massachusetts Department of Revenue 


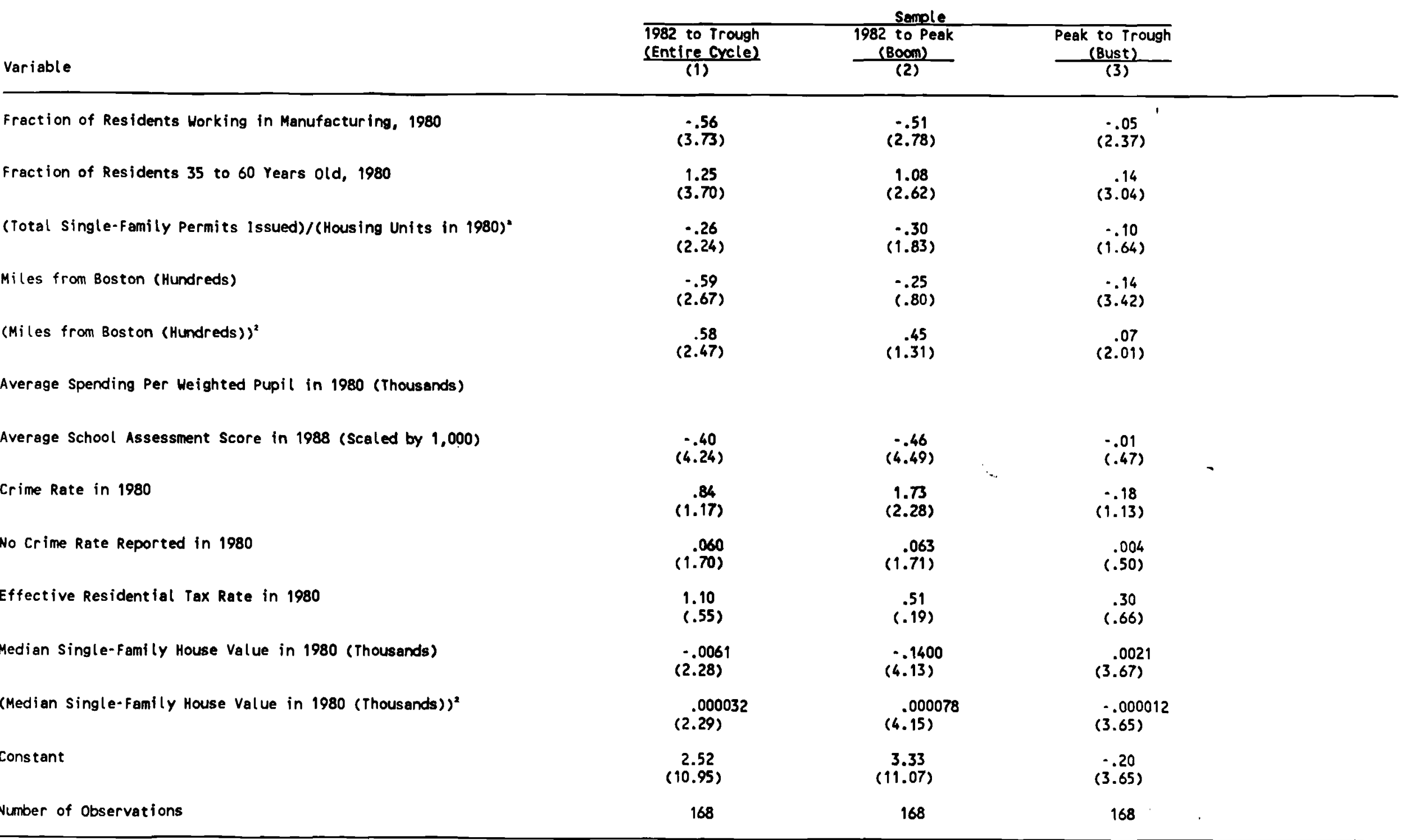

Notes:

1) Estimated standard errors are heteroskedasticity robust as in thite $(1980)$

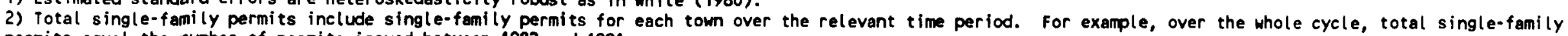
permits equal the number of permits issued between 1982 and 1991.

3) The index values for the peak and trough are computed separately for each town, and correspond to the date of each town's respective peak and trough.

instruments for total single-family permits include the number of permits issued in previous periods and the amount of vacant land in 1984. 